Published in Mediterranean Politics, full reference:

Casier, Marlies (2010) 'Designated Terrorists: The Kurdistan Workers' Party and its Struggle

to (Re)Gain Political Legitimacy', Mediterranean Politics, 15: 3, 393-413.

If you refer to this article, please refer to the published version listed above.

\title{
Designated terrorists. The Kurdistan Workers' Party and its Struggle to (Re)Gain Political Legitimacy.
}

Marlies Casier, Ghent University, Middle East and North Africa Research Group ${ }^{1}$

\begin{abstract}
The European Union designation of the Kurdistan Workers' Party as an international terrorist organization has led to a profound distrust of the EU on the part of the PKK. This has resulted in a perception that the Kurdish organization has turned against the EU and withdrawn its support for Turkey's accession. The PKK activities and viewpoints as presented and discussed in this article, however, indicate that this is not the case. Politically squeezed at home and sidelined abroad, it is argued, the PKK is, in fact, primarily concerned to (re)gain recognition as a representative of Turkey's Kurds (upon which it is making its support for Turkey's accession conditional).
\end{abstract}

\section{INTRODUCTION}

As of 2002, the Kurdistan Workers' Party (Partiya Karkerên Kurdistan, the PKK) found itself designated an international terrorist organization. The international proscription of the PKK that came with its entry onto the EU, US and UK terrorist lists constituted the beginning of a new era for the main actor in Turkey's Kurdish nationalist movement. Having waged an insurgency war against the Turkish state since 1984, the PKK had long been branded 'terrorist' by the Turkish state, and the civil disruption and criminality associated with the

\footnotetext{
${ }^{1}$ This research paper fits within a broader research on transnational political organization, for which the author is grateful to have obtained a research fellowship from the Research Foundation - Flanders, FWO.
} 
organization and its affiliates in Europe had led Germany and France to order the closure of the organization's branches in their territories during the mid 1990s. Nevertheless, the classification of the PKK as an international terrorist organization in the wake of September $11^{\text {th }}$ was particularly hard to digest for the party and its followers - so much so that the Europe-based PKK-related organizations have devoted much of their time to divesting themselves of the 'terrorist' stigma and restoring the organization's legitimacy as a socialpolitical movement. To this end, legal and political activities as well as socio-political protest events have been staged in Europe. These activities attest to ongoing (albeit weakening) efforts of the Kurdish nationalist movement's main actor to capitalize on international support, in particular with regards to the EU member states and its institutions, which are in continuing negotiations with Turkey over its possible future accession.

This paper bears testimony to a deepening sense of distrust on the part of the PKK towards the EU institutions that had previously served it well, and attests to an ongoing struggle by the former for the creation of a political space that is inclusive of the organization deemed to represent Turkey's most politicized Kurds. Consequently, these findings reject the thesis of Uslu (2008), that since late 2005 the PKK has sought to actively undermine the Turkey-EU accession negotiations. The findings reported here indicate that what has been happening is best understood not as a move by the PKK away from the EU, but as an ongoing attempt by the organization to be incorporated into the negotiations over Turkey's future, and thus the future of Turkey's Kurds, as well as a concern for its own survival, especially as the centre of gravity in Turkey's Kurdish activism moves from violent to peaceful means, participating in rather than excluded from the country's political system. In other words, the PKK is not seeking to actively undermine Turkey's accession to the European Union, but has turned its own political recognition into the condition for its support.

This paper begins with a brief introduction of Turkey's Kurdish question, focusing particularly on how the PKK and its political wing or allies have evolved since the start of its insurgency in 1984 up to the present. Then, special attention is drawn to PKK's installation and activities in Europe since the mid 1980s. This is to serve a better understanding of the effects of the listing for the PKK's operational space in Europe, as well as the current initiatives undertaken in the light of the terrorist designation. After elaborating on the consequences of the terrorist labelling and how it was received by PKK political activists and sympathizers, the paper explores the initiatives aimed at (re)gaining political legitimacy in the international political arena, upon which support for Turkey's accession to the European 
Union is made conditional. The value of the terrorist designation itself - moral, practical or otherwise - is not the main concern of this paper, it should be emphasized, but rather the impact of the designation on the PKK positioning in relation to the European Union.

\section{BACKGROUND}

\section{The Kurdish Question in Turkey and the armed conflict with the PKK}

In the inter-war period when the Republic of Turkey arose from the remains of the Ottoman Empire, Mustafa Kemal (Atatürk) led a revolutionary reconstruction of the territory. This involved, among other things, a nationalist project of 'Turkification', and in mainly Kurdish provinces of the south-east of the country, a series of rebellions was crushed (McDowall, 1996; Taspinar, 2005; Jongerden 2007). By the 1950s, Kurdish (and other) identities had been technically cleansed by the 'Kemalist' ideology (Kurds were re-designated as 'mountain Turks'). Various forms of martial law and direct rule from Ankara were applied, and further post-war periods of repression followed a succession of military coups (1960, '71, '80). It took until the end of the 1960s for Kurdish dissidents to politically reorganize, and it was only in the mid 80s that Kurds took up arms again, with a fully-fledged insurgency instigated against the Turkish state.

Officially established in 1978, the PKK started its armed insurgency in 1984, which, although interrupted by ceasefires of varying durations, continues to this day. The PKK initially aimed at 'a destruction of colonialism' - referring to all the state-forces 'occupying' the Kurdish populated region of the north-western Middle East (i.e. including territory in Syria, Iraq and Iran, not just Turkey - and 'the construction of a democratic and united Kurdistan, based on Marxist-Leninist principles' (Jongerden \& Akkaya, 2011). After the 1980 coup, which had led to the imprisonment and exile of almost all leftist and Kurdish nationalist party leaders and militants, the PKK leadership fled Turkey for Syria. This left the party one of the very few radical leftist or Kurdish organizations in or from Turkey that was still operational (Jongerden \& Akkaya, 2010). The PKK set about implementing a guerrilla war on Maoist principles, through which it was able to effectively takeover large tracts of the countryside in the southeast by the early 1990s. The Turkish military responded, however, and the tide was turned. By the beginning of the millennium the state had largely regained control of the situation, by a 
variety of legal and illegal methods. ${ }^{2}$ The security situation today remains tense and unresolved, with a small but steady stream of deaths on both sides and unrest in cities.

After the capture of its leader and co-founder, Abdullah Öcalan, in 1999, the PKK transformed itself ideologically and organizationally, upon Öcalan's guidelines passed through lawyers from his prison cell on the island of Imralli (Marcus, 2007a; Gunter 2008). The PKK today no longer advocates separation from Turkey as official policy, but seeks the transformation of - and its integration into - a democratized, confederalized Turkey (Akkaya \& Jongerden, 2011).

The PKK has sought to engage in negotiations for a peace agreement on several occasions, starting from 1993, when it first called upon Turkey to end the fighting by announcing a unilateral ceasefire. Other unilateral ceasefires followed - the longest in the period 1999-2004 - but Turkey has tended to interpret these as a sign of weakness and/or the result of military defeat, and uses the terrorist label to avoid direct, open talks. Unfortunately, tragically even, this is a misreading of the enemy on the part of the state that represents a history of wasted time and lost opportunities. The assumption, especially since Öcalan's capture, that PKK peace moves have been forced by military weakness is erroneous insofar as these have been importantly rooted also, arguably more so, in the organization's increased capacities, its ability, that is, to operate within the political framework of the state (and Europe) in raising mass popular support and developing organizational networks (based in the Kurdish cities inside Turkey and amongst the Diaspora in Europe). The emergence of its press and establishment of pro-Kurdish parties as mentioned, along with, for example, huge demonstrations in support of slain guerrillas have long confirmed to the PKK the strength of other action repertoires besides classical Maoist insurgency.

Coincidently, it was during the period around the international terrorist listing of the PKK, that the pro-Kurdish Democratic Society Party (Demokratik Toplum Partisi, DTP) established itself, with representation at both the national and the local levels. The DTP was generally seen as the political wing of the PKK, although this was unclear (necessarily, given the PKK's terrorist status at home) and thus sometimes queried by outsiders, or just allowed to remain ambivalent. ${ }^{3}$ Compared to its predecessors HEP (1990-1993), DEP (1993-1994) and HADEP

\footnotetext{
${ }^{2}$ Legal methods: e.g. the reorganization of the army for counter insurgency; illegal methods: e.g. extrajudicial killings, the evacuation and destruction of around 3,000 villages and hamlets (see Jongerden, 2007).

${ }^{3}$ E.g. ' $[\mathrm{I}] \mathrm{t}$ is an open secret that the party [DTP] is somehow related to the PKK (Posch, 2007: 39, emphasis added).
} 
(1995-2002), which mainly operated during the heat of the conflict and were thus severely confined, DEHAP (2003-2005) and DTP (2005-2009), working in a less tense political climate, were able to promote more concrete political programs that incorporated the (changing) goals of the PKK (see below).

The Kurdish political parties began to run an increasing number of municipal authorities in the South-East after the 1999 local elections, rising to as many as 54 municipality mayors across eleven provinces, and nine mayors of the provincial capitals by the end of the decade, while the DTP was represented in parliament by 21 MPs following the 2007 national election (elected as 'independent-candidates' in order to circumvent Turkey's $10 \%$ electoral threshold). It was through the DTP control of the region, especially of the municipalities, that the PKK was able to maintain and even extend its dominance and popularity there (Marcus, 2007b).

The DTP can thus be regarded as putting into practice the new ideological project advocated by Abdullah Öcalan, with many of its political representatives themselves former activists (or 'activists in office'), and pursuing the contentious politics of a (Kurdish/minority/human) rights based agenda (Watts, 2006). Many authors have testified to how the lifting of the state of emergency in the South-East in the 2000s opened the way for a more self-conscious Kurdish associational life, and how the DTP run municipalities contributed to the emergence of a new Kurdish public sphere (e.g. Öktem, 2008; Gambetti, 2008; Marcus, 2007a and 2007b; Watts, 2006). At the end of 2009, however, following an indictment two years previously, the DTP was finally closed - like other pro-Kurdish parties before - found to have violated Article 68 of the Constitution (i.e. in conflict with the 'independence of the state' and 'indivisible integrity' of its territory and nation). Upon the banning of the DTP, the proKurdish party was promptly replaced by its successor - again, as on previous similar occasions - the pro-Kurdish Peace and Democracy Party (Bariş ve Demokrasi Partisi, BDP).

\section{Increased competition over the political representation of Turkey's Kurds}

The new Kurdish public sphere has been developing simultaneously with an increased political competition over the representation of Turkey's Kurds between the Kurdish nationalist movement and Turkey's ruling party since 2002, the conservative Muslim Justice and Development Party (Adalet ve Kalkınma Partisi, AKP). Constituting the first majority 
government for a generation and successfully pushing forward the necessary political and economic reforms for the country to become a candidate for full membership of the EU, the AKP has generally found favour in Brussels. The coming to power of the AKP has also significantly affected the Kurdish issue in Turkey, including the PKK (Bahcheli and Sid, 2011).

Although continuing a process that had actually been initiated by the previous government, it was the AKP that officially ended the state of emergency. Through this initial engagement with reforms, the AKP government managed to present itself as a party actively seeking to integrate different ethnic and religious minorities in Turkey and devoted to the 'democratization' of the country. This enabled the party during its first years in office to extend its electoral support amongst Turkey's Kurds, as well as gain favour amongst those within the EU institutions in favour of the country's accession.

As a result of the success of the AKP, particularly during its first administration, the DTP, like its predecessors, not only experienced continual political isolation inside Turkey (see Öktem, 2008), and repeated demands that it distance itself from the 'terrorists' (PKK) - a call echoed in the EU-Turkey accession negotiations (see below) - but it has also found itself under pressure in its natural constituency. Electorally, the DTP found itself in competition with the $\mathrm{AKP}$, and the PKK began treating what had become its main rival as its number one enemy (even above, that is, the Kemalist state military), with its media and leadership actively involved in efforts to discredit the ruling party (Uslu, 2008). This has taken the form of targeting not only AKP intentions regarding the Kurdish issue, but also its politics more generally. Although the DTP was triumphant in the 2009 local elections, the Kurdist party (now BDP) continues to regard the AKP as its biggest threat.

All of which rather begs the question: are the AKP and PKK/DTP/BDP merely involved in a turf war for the political ascendancy, or do they have genuinely different visions for the way ahead? This is relevant not just for a better assessment of the PKK and what has transpired in terms of its approach to Turkey's EU accession over recent years, but also because it might give clues about the likely future of these. A brief review of events last year gives some clues here. In the spring of 2009, the AKP opened a new era of public debate in Turkey in respect of the Kurdish issue when it announced the launch of a Kurdish initiative (Kürt açılım), intended to solve the longstanding problem of the South-East. By the end of the summer, 
however, it had become clear that the government would neither engage in direct, open political dialogue with the PKK, nor accept the DTP as interlocutor.

Under extreme pressure from the establishment (the judiciary and the military), and the two main opposition parties (Turkish nationalist and Kemalist), as well as large sections of the media, the AKP first broadened and diluted its Kurdish initiative to a democratic one (demokratik açılım), which focused instead on other social groups (Alevis, Romani Gypsies) and a normalization in foreign relations (with Turkey's Eastern neighbours). Then it confined its solution to the Kurdish question to cultural and linguistic aspects (e.g. loosening restrictions on Kurdish language use), while shelving the more difficult political issues (e.g. relevant changes to the constitution, what to do with the PKK).

Cotemporaneous efforts by the PKK and DTP that sought to steer the initiative in the direction of negotiations - by means of the submission of Öcalan's Roadmap in the summer of 2009, and the symbolic return of groups of PKK members and families from the mountains and the Mahmur Refugee camp in Iraq - only increased the establishment and opposition parties' critique of the whole initiative as a surrender to the 'terrorists'. Öcalan's attempted involvement was rejected and his roadmap misplaced by the authorities. The crowds and DTP motorcade that greeted the returnees, meanwhile, were perceived as provocative, appearing to the country at large as rather shocking images of PKK victory celebrations. Indeed, it was shortly after this incident that the DTP was banned, paying the price, many would argue, for a major strategic blunder, its own misreading of the other side and wasting of an opportunity (Jenkins 2009; Casier, Hilton and Jongerden, 2009).

To a certain extent the restriction of the AKP Kurdish initiative has been due to the small room for manoeuvre the government has. Its continued failure to really follow through with its professed aims, however, has fuelled cynicism about the initiative, as primarily dictated by electioneering politics. Certainly the AKP seems to have assumed the old economic analysis that has Kurdish discontent as originating from poverty and under-development rather than oppression and disenfranchisement. Through the resumption of the old GAP plans, a vast dam project for land irrigation and hydro-electric power, it seeks to tackle the economic grievances that are thought to underlie PKK support in the region and thus deny 'terrorism' its breeding ground. Given the general reluctance of the government to engage in any form of political dialogue and its recent reframing of the initiative as the ultimate struggle against 'terrorism', therefore, Turkey's Kurdish movement has increasingly felt driven into a corner (and all the 
more so with the closure of the DTP and ongoing raids and arrests of BDP members in the first half of 2010).

To conclude, both Turkey's Kurdish question and its main actor have evolved considerably over the last decades, not only since the beginning of the armed conflict in the mid-1980s but also since the PKK terrorist designation early in the millennium. In addition to its lengthy unilateral ceasefires and change of ideological tack from secession to federalism, the role played by the DTP/BDP in conventional politics has made it even more difficult to pin-down where the presence of the Kurdistan Workers' Party in Kurdish society really begins or ends, complicating its designation as 'terrorist'. At the same time, a competition has developed with the ruling AKP for the claim to represent Turkey's Kurdish population in the region, played out in the media and at the ballot box. This has given rise to a deepening animosity between the Kurdish nationalist movement and the current Turkish government, and forms the background against which the narrative of this paper should be understood. The PKK and its supporters have perceived themselves to be doubly confined, first by the international terrorist designation and second by the political challenges they face inside the region, and it is this particular combination of confinements that has informed the recent approach of the PKK to Turkey's EU application. Furthermore, it might be added, the current situation (i.e. in respect of the lack of progress or hope even of such from the AKP's Kurdish/democratic initiative) indicates that the present dynamic will be a continuing one.

\section{THE PKK PRESENCE IN EUROPE}

The PKK 'struggle' did not remain confined to the Kurdish region of Turkey and its neighbours, but was continued on European soil, where the PKK established itself very early on in its history. Among the growing European Kurdish Diaspora, there developed a transnational Kurdish community which included the cross-border political organization of Kurds from Turkey (Grojean, 2008; Watts, 2004; Adamson, 2002; Östergaard-Nielsen, 2001; Van Bruinessen, 1998).

The pro-PKK associations, set up since the mid 1980s proved helpful in obtaining public and political support among European Kurds, within a section of European public opinion and from a number of European politicians. Solidarity networks were built-up with small, extreme leftist organizations that were ideologically close to the PKK. Contacts were developed 
between leftist and Kurdish nationalist politicians holding seats in regional and national parliaments in different European countries as well as in the European Parliament (Casier, 2011). This provided the PKK and its sympathizers with concrete means to advocate their cause and to publicize the plight of Kurds living in Turkey, particularly during the height of the armed conflict. PKK militants could collect financial contributions from European Kurds, call for hunger strikes and demonstrations, set up a satellite television station, radio stations and newspapers (Grojean, 2008; Watts, 2004; Eccarius-Kelly, 2002) and develop their own network of 'diplomats', all of which gave leverage to an increased visibility of their promotion of the Kurdish cause.

The tolerance of PKK activities and criticisms coming from European politicians enraged the Turkish authorities, whose embassies and diplomats were continually engaged in attempts to discredit the Kurdish organization (e.g. as funded by the narcotics trade and extortion from the European Kurdish populations). Turkey pressured the western European governments to crack down on PKK activities on their soil, threatening them in turn with withdrawal from economically important contracts and lucrative arm deals (Grojean, 2008). This pressure gradually began to take effect, with increased governmental surveillance of PKK activities in a number of European countries. Although this was largely ineffective, it did pave the way for Europe's acceding to Turkey's request to list the PKK as an international terrorist organization.

\section{THE LISTING OF THE PKK AS AN INTERNATIONAL TERRORIST ORGANIZATION}

The first country in Europe to list the PKK as a terrorist organization was the UK. With a thirty-year history of 'terrorism' in Ulster / Northern Ireland, the UK responded quickly to the changed environment following the 9/11 attacks in the US, and, as of $28^{\text {th }}$ March 2001, the PKK found itself officially listed as a terrorist organization alongside eighteen other foreign organizations active in the United Kingdom (UK, 2001). The EU started listing organizations and individual as terrorists from December 2001 onwards, when it largely copied the regulation worked out in the US Patriot Act drawn up during the year 2000 motivated by the 9/11 attacks and principally with Al-Qaeda / the Taliban in mind. The first EU list of 29 individuals and thirteen groups and entities included national insurgent movements (ETA, Real IRA, etc), but omitted the PKK (EC, 2001). This was soon amended, however, and in the spring of 2002 the PKK was proscribed in Europe, included among the expanded listing of 23 
groups and formally named as 'involved in terrorist acts' by the Council of the European Union (EC, 2002 :1). ${ }^{4}$ The original EU decision to place the PKK on the terrorist list has been confirmed since by the six-monthly review of the list, to which the post-2004 casualties and bomb attacks attributed to the PKK or claimed by TAK (Teyrêbazên Azadiya Kurdistan, Kurdistan Freedom Falcons), an affiliated splinter-group, undoubtedly played a significant role

Officially, the international terrorist lists were aimed at targeting the funding of terrorism, through travel restrictions and the freezing of assets. Their real aim, however, was political, as acknowledged by the EU Anti-Terror Coordinator, Gilles Van de Kerckhove: 'The reasons are political. You say that it is a criminal organization, not a political organization. That is the message' (Van de Kerckhove, $20^{\text {th }}$ October $2009^{5}$ ). Interestingly, the message was not necessarily intended to be entirely one-sided, at least not in the case of national insurgencies. In fact, executives like Van de Kerckhove go so far as to regard the lists as 'assets', to employ against the state as well as insurgents. In particular, on Turkey, he argued that 'The list can be a means to leverage, to pressure Turkey to respect its minorities and human rights,' implying that international recognition of Turkey's 'terrorism problem' would facilitate the engagement of the Turkish authorities with the EU's political concerns.

However, the extent to which the lists are necessary, really can be and actually are being used as leverage to pressure the different parties in the conflict is debatable. In Turkey's case, first, its desire to join the EU is already leverage in itself, with vastly more traction than anything the terrorist listing can provide; second, the existence of the lists certainly appears to have an opposite effect, i.e. to support those state actors that do not want to enter into negotiations for peace, but to proceed with a conventional counter insurgency approach against non-state combatants; and third, the listing has also undermined certain human rights in respect of the organizations listed, such as the freedom of expression and association.

On this point the EU action can be considered problematic. Turkey's problem with human rights has been one of the principle obstacles in its entry passage to Europe, and the Kurdish

\footnotetext{
${ }^{4}$ In May 2004, the ban was revised to 'Kurdistan Workers' Party (PKK), (a.k.a. KADEK; a.k.a. KONGRAGEL)' (EC, 2004), in recognition of the internal restructuring of the party (see Akkaya \& Jongerden, 2010). For ease of reference, this paper will only use the name 'PKK', which should be understood as standing for KADEK and sister organizations as appropriate.

${ }^{5}$ From a speech given at the conference 'Terrorism lists, executive powers and human rights' at the Université Libre de Bruxelles.
} 
issue in the South-East the major part of this. And yet the EU seems not only to fall short of its own standards (the standard critique of Western anti-terror legislation taking on a sharp irony here), but also to have been guilty of a major disconnect in failing to appreciate that its terrorist designation would exacerbate the very human rights abuses it condemns. Thus, recent EU reports note concern about Ankara's 2006 amendments to its Anti-Terror law (EP, 2008), leading to the entirely predictable conclusion of 'undue restrictions on fundamental human rights' (EC, 2009: 30). ${ }^{6}$ In the eyes of the PKK, the EU is culpable in this for its branding of the organization (see below), which the same reports only confirm when, for example, the European Parliament 'reiterates its solidarity with Turkey in its fight against terrorism and once again calls on the PKK to declare and respect an immediate and unconditional ceasefire' (EP 2008: 9).

Obviously there is a need for the EU to confirm to Turkey that it can be a trusted partner that shows genuine concern for Turkey's internal and regional stability - Turkish sensitivities cannot just be ignored. This means that simple de-proscrition is not a realistic option. Most probably it needs to be linked to progress towards a negotiated resolution of the conflict, which would seem to mitigate for a deep involvement on the part of the EU in Turkey's 'peace process'.

Unfortunately, such a proactive approach by the EU has not been forthcoming. Instead, therefore, a one-sided policy has led the PKK's designation as a terrorist organization to become deeply ingrained in the accession negotiations. As a result, the main problems concerning the lack of willingness to reform on the Turkish side are linked to the ongoing and recently increased uncertainty about Turkey's entry into the European Union. The lack of anything like a complete commitment to Turkey by the EU means, therefore, that the effect of the designation remains questionable in this regard. It may well be that the PKK terrorist designation works against conflict resolution and thus exacerbates the human rights situation in the South-East which therefore continues to drag on Turkey's accession process leaving Turkey to 'sort out its own mess' before accession can even be countenanced - a prospect which, frankly, would not unduly worry many in Europe and, unfortunately, does appear to be the most likely scenario for the short to medium term future.

\footnotetext{
${ }^{6}$ The European Commission staff report notes that the amendments have provided for children aged 15-18 to be tried as adults on charges of 'belonging to a terrorist organization', resulted in the 'suspension of several periodicals' and been used to 'punish non-violent opinions', causing hundreds of politicians and the members of two trade unions to be arrested, with one politician sentenced to eighteen months in prison for his speeches (EC, 2009: 21, 25, 30).
} 
While practical anti-terrorism measures have affected the PKK and its militants and sympathizers to some extent, curtailing some activities, the de-legitimizing effect is crucial. The labelling has had profound effects on the political and societal space for the Kurdish movement both in Turkey and in Europe - so much so that the majority of PKK initiatives undertaken at the diplomatic level have been to address the labelling and its consequences, rather than straightforwardly articulating grievances and demands and advocating for Kurds in Turkey.

\section{FACED WITH THE TERRORIST DESIGNATION}

Taking an agency-oriented perspective, which incorporates the ways in which actors present their problems and develop coalitions (Smith \& Bakker, 2005), the following sections engage with how the listing has been received inside the circles of PKK militants and sympathizers. Having the actors 'speak for themselves' is not meant to provide a platform to proclaim and/or promote their aims and means, but allows a better understanding of these actors and their collective psychology that steers strategic choices being made. The response to the listing and an assessment of its effects are contextualized here in the relationship between the PKK and the EU institutions.

\section{'European states are being taken hostage by Turkish Policies' - proscription as betrayal}

The proscription of the PKK as a terrorist organization and the condemnations of terrorism in EU official communications have been perceived as a betrayal by the leading figures in the PKK and their followers. Engaging in an inquiry of this shared sense of betrayal is important in order to understand the anti-EU rhetoric of a number of leading figures within the PKK that has followed the terrorist listing (as described by Uslu, 2008), and, at the same time, the continuation of the PKK's engagement with the European Union.

The feeling of betrayal relates strongly to both the timing of the first proscription and a 'politics of suffering'. Regarding the timing, the PKK was defined as a terrorist organization not only during a long period of (unilateral) cease-fire but also following Öcalan's scaling back of conditions for a solution to the Kurdish issue, as he openly argued that the problem in Turkey's south-east would be resolved by meeting cultural demands of the Kurds, thereby shifting the goal of political autonomy to the background. The ceasefire and scaled back demands were understood inside the movement and by its followers as a genuine display of 
the PKK desire to resolve the Kurdish issue by non-violent means. Being labelled as a terrorist organization, therefore, was experienced as a refusal to engage with the PKK - and by extension the Kurds - and clearing the way for a state-led approach to the issue. Considering the high-levels of Kurdish distrust of the Turkish state, it should have come as no surprise that conspiracy theories were soon circulating in the Kurdish media, or that a sense of betrayal by 'the West' or 'Europe' would become widespread among activists and supporters in Turkey and Europe. One human rights activist expressed his feelings thus:

'Europe is following Turkey's line in calling our struggle 'terrorism'. We are unhappy about the results of the European delegations that have come here. We show them everything, we take them to the destroyed villages, we talk to the families and so people relive their sufferings again, but there is no change to be seen at all. On the contrary, the movement is being called terrorist' (Personal communication, Diyarbakir, 14 September 2007).

The PKK sense of betrayal also needs to be understood in the light of suffering and sacrifices made by these Kurds and their communities in the armed conflict between the PKK and the state. In many of the interviews conducted by the author, Kurdish political activists have expressed their frustrations about the terrorist listing in these terms. Activists also relate more generally to 'a politics of suffering' that is actively maintained - through the commemoration of martyrs and significant traumatizing events - as a means both to keep in remembrance the unsettled accounts with the Turkish state and to continue to unite people under the PKK umbrella. $^{7}$

Concerns over the designation have been raised continuously in public political meetings in Europe. The following example, from an international conference on the EU and the Kurds, develops further the equation of PKK with (Turkish) Kurds, essentially a discourse of (assumed or claimed) representation:

'There are 20 million citizens of Kurdish origin [in Turkey] but still they present it as if it is a problem of terrorism. But the people have legitimate rights and they are not defending separatism. They seek peaceful coexistence. Autonomous regions are necessary in order to

\footnotetext{
7 The demonization of terrorism and the glorification of freedom fighting both, of course, ignore the (extra)ordinary costs of human suffering that activists and their familes pay, extending to that of their lives; equally, however, the suffering of non-activist Kurds is 'claimed' by the PKK, even though those people themselves may be ambivalent about or even resent the PKK. These points are made just to give a sense some of the issues involved in the PKK sense of suffering - many more could be listed (and for both sides, of course).
} 
freely live our identities. If you do not live up to any of these legitimate demands then it looks as if the Kurds are the cause of the problem. Is the EU aware of who is really responsible for the failure to find a solution: the Kurds or the state? To picture the Kurds as terrorists is unfair and ignoble. This has been a 25-year process that caused great suffering for Kurds and Turks....' (Ahmet Gulabi Dere, diplomat for the KNK Brussels, 28 January, 2009 ${ }^{8}$.

Such words testify to the shared sense among PKK activists and sympathizers that the organization's terrorist designation has turned Kurds into the guilty party, from the victims of violence into its perpetrators, while 'the state' appears to escape blame. There is thus a collective feeling of being let down and misunderstood, confirming - in their eyes - the popular saying that 'Kurds have no friends but the mountains.' This partly explains the PKK's unwillingness to refrain from maintaining its armed guerrilla forces, and its employment of a sporadic 'dialogue through arms'.

'Those who go against the state system are being considered terrorists. But the solution lies in dialogue, the democratic method. [...] They say that PKK is terrorist. No, PKK is the consequence and if the cause does not change, than the consequence will not change. PKK can lay down its weapons, but in the past this was always left unanswered. (Abdullah Demirbaş, then DTP Mayor, $2^{\text {nd }}$ October 2008). ${ }^{9}$

\section{'This is the wall that we are facing' - diplomatic constraints}

The European Parliament and the European Commission have both voiced their support for Turkey's struggle against terrorism in making calls for a peaceful solution. For example, the 2009 Progress Report by the European Commission described the situation thus:

'During the reporting period Turkey faced continuous terrorist violence resulting in loss of life, despite a relative reduction of violence from the end of 2008. In December 2008 the European Union reaffirmed its support to Turkey in the fight against terrorism, which must be conducted with due regard for human rights, fundamental freedoms and international law' (EC, 2009: 30).

The political wing of the Kurdish movement, the DTP/BDP, has continuously voiced criticism of the EU's terror designation as a way of dealing with the conflict, as obstructing any kind of official negotiation of national actors with the PKK. Regardless of the validity of

\footnotetext{
${ }^{8}$ From a speech given at the 5th EUTCC International conference on Turkey, EU and the Kurds, in the European Parliament, Brussels.

${ }^{9}$ From a speech given at the conference on the EU-Turkey accession process, held by the Kurdish Institute of Brussels at the House of Parliamentarians, Brussels, 2nd October 2008.
} 
this analysis - the PKK is officially ostracised from involvement in any internal process anyway by the Turkish state terrorist designation - the links that the DTP/BDP have had to the PKK have certainly caused them also to be directly affected by the designation. The sense that Europe was culpable in the DTP closure is hard to deny when the EU clearly implied that it was not working constructively in the political sphere:

'[The EP] ... Calls on the DTP, its members of parliament and mayors to distance themselves clearly from the Kurdistan Workers' Party (PKK) and to engage constructively in the quest for a political solution to the Kurdish issue within the democratic Turkish state' (EP, 2008).

Turkey's Kurdish question has long figured on the EU agenda (Tocci, 2005), and members of both the European Parliament and the Council of Europe continue to engage with Kurdish political activists who obviously have strong affiliations with the PKK. There is thus a clear implicit recognition of and support for at least some of the demands of the Kurdish movement. Nevertheless, while the cause might be seen as just and legitimate, most European politicians do not want to (be seen to) legitimize the PKK's leading role in formulating and presenting it (Casier 2011). As a result, there is no public acknowledgement of the PKK as one of the main representatives of Kurds from Turkey, which confirms the international public image of the PKK as nothing more than an armed terrorist organization and prevents recognition of it as, at the same time, a social and political movement enjoying considerable popular support (Eccarius-Kelly, 2002; Romano, 2006; Akkaya \& Jongerden, 2010). In the words of one activist-journalist:

'The PKK is called a terrorist organization and the DTP cannot criticize that? But how can you explain that hundreds of thousands Kurds take the streets in Turkey and Europe with the same demands? Are they all terrorists? That is a scandal! ${ }^{10}$

There is an awareness amongst PKK militants that public recognition of their popular support would counteract the one-sided attention drawn by the Turkish state and now Europe and the USA to the 'terrorist' (and common criminal) activities of the PKK (Casier, 2011). And insofar as the DTP/BDP is seen as the political wing of the PKK, then its increasingly strong showing at local and national elections confirms this to the tune of several millions of votes. ${ }^{11}$ Unfortunately, however, the War on Terror has complicated the already problematized understanding of armed conflicts and how these can be solved (Sheper-Hughes \& Bourgeois,

\footnotetext{
${ }^{10}$ From an intervention from the floor during the conference on the EU-Turkey accession process (ibid.).

${ }^{11}$ During the 2009 local elections the DTP almost doubled its number of municipality mayors, and attained the highest local assembly winning margins in the country.
} 
2008). The upshot of all this in Europe has been to devote attention to pressing the government of Turkey on the matter of the cultural rights of Kurds, and paying less heed to the political demands of the Kurdish movement and the need to create a positive climate for peace negotiations. This has lead to increasing scepticism within PKK circles of the role the EU is willing to play in the resolution of Turkey's Kurdish question by means of the accession process. As one leading PKK member puts it:

'As Kurds we have supported this process. We have worked hard in order to convince the people to give a date for the start of the accession negotiations. But when I look back now at what has happened, since the negotiations started, when we look at the Kurds present here today, than this is not an improvement. I wonder if we made the right choice to support this process? (...) Things are not progressing. With the support of the EU, Turkey is increasing the repression of the Kurdish people. Since the accession negotiations started, Kurds in Europe too have come to be looked upon as terrorists, with the support of certain European countries, such as Germany and France. [... ] If Turkey is willing to respect the criteria [of Copenhagen] then we will be in favour of accession, if it does not, than we will not be supportive.' (Ahmet Gulabi Dere, diplomat for the Kurdish National Congress in Brussels, 2008). ${ }^{12}$

In the latest EUTCC Conference on Turkey and the Kurds in the European Parliament (February $\left.3^{\text {rd }}, 2010\right)$, DTP/BDP Member of the Turkish General Assembly Sebahat Tüncel argued:

'The discourse on terrorism has been enormously damaging and it is the reason why the fact that DTP parliament members are sentenced to jail is not being discussed. [...] The task for our European friends is to create opportunities for dialogue, and that is why it is necessary to put the concept of terror to discussion because now this is the wall that we are facing.'

A number of Kurdish activists, leading militants of the PKK in Europe especially, have come to see the EU as merely working in Turkey's interests and against that of the Kurds. Adem Uzun, KNK Foreign Affairs member, reviewed the EU reports referred to thus:

'[I]n the post 9/11 period, taking courage from "the war against terror" and the "you are either with us, or against us" doctrine, Turkey escalated the war yet again. [...] What we essentially would like to point out is that the EU's approach is prejudiced, more so, it regards the matter within the framework of the demands of the Turkish state. [...] As a result, the EU reports justify state violence. [...] The EU reports tend to impose [conditions] upon Kurds, even

\footnotetext{
${ }^{12}$ From a speech given at the conference on the EU-Turkey accession process, held by the Kurdish Institute of Brussels at the House of Parliamentarians, Brussels, 2nd October 2008.
} 
ignoring their democratic rights by telling Kurds what kind of leaders they should choose for themselves' (Uzun, at the EUTCC conference, February 2010).

The charge against the EU of prejudice obviously needs shading - the EU is not a monolithic body with one single opinion. Support for the Kurdish cause in the Parliament comes mostly from the leftist parties, with centrist liberals also advocating for human rights (Casier 2011), but the parliament as a whole moved to the right at the last (2009) election, while the seat of EU power remains the Council, which always tends to be more conservative than the Parliament. The lack of action or outcry from Europe when the DTP was closed down testifies to the diminished support for the Kurdish party from within the EU institutions. This regardless the ousted criticisms by the Council of Europe, the Commission as well as the European Parliament on party closures in Turkey. Nevertheless, voices supportive of the Kurdish cause are to be heard. In respect to the pre-closure pressure on the DTP, for example, Olli Rehn (former EU Commissioner for Enlargement, responsible for overseeing Turkey's candidacy), backgrounded the terrorism issue in coming out clearly in support of the party:

\footnotetext{
'We have consistently stressed that the fight against terrorism must be conducted with due regard for human rights and fundamental freedoms, in particular as regards freedom of expression and freedom of association. Political pluralism is an integral part of any democracy. The Turkish parliament is today largely representative of the country's political diversity. DTP has been contributing to pluralism in Turkey, with its political legitimacy confirmed by the results of the March municipal elections. At the same time, the people of the Southeast of Turkey need peace, stability and prosperity rather than further violence and confrontation. [...] In this context, we have reiterated to Turkey that the Turkish legal provisions governing the closure of political parties are not in line with the European Convention of Human Rights and with European practices' (Rehn, 2009, emphasis added).
}

In direct contacts with EU politicians, however, it is the case that DTP/BDP representatives have been continuously asked to dissociate themselves from the PKK or to clarify their relationship. In a discussion with the then leader of the DTP group in the Turkish General Assembly (and current co-chair of the BDP), the DTP/BDP position on this was outlined in no uncertain terms:

'We are not going to consider the PKK a terrorist organization. We have to explain this in Europe too. Terrorist organizations in Afghanistan and Iraq are terrorist organizations. What is a terrorist organization and how should we combat it, is an important question. But the PKK 
does not belong in the list, because it has different roots, different reasons of existence and its fight is a different fight' (Selahattin Demirtaş, personal communication, Diyarbakir, 22 September 2007).

The closure of the DTP has, in this regard, played out in favour of the PKK's holding on to its arms. In fact, the terrorist listing can be said to have polarized politics in the south-east of Turkey. Kerckhove's 'asset' for 'leverage' (above) has had the effect of hardening support for the 'terrorists'. Shortly after the DTP closure, for example, its leader went on record for the first time to state the role of Öcalan in his party's politics. ${ }^{13}$ This is also acknowledged by Kurdish politicians who are not associated with the PKK or DTP/BDP, such as Haşim Haşimi, former Welfare Party MP and former Mayor of Cizre:

\begin{abstract}
'Whoever says that the PKK is a terrorist organization will not gain any votes anymore. You cannot ignore the reality. The shadow of Öcalan is there and to call him a terrorist will not solve the problems' (Personal communication, Diyarbakir, 20 September 2007).
\end{abstract}

Being labelled 'terrorists', therefore, has increased the symbolic political and societal isolation of the PKK and affiliated organizations in Turkey and in Europe, increased the felt sense of injustice experienced by activists, and played a part in the muzzling of their views as expressed in conventional arena of party politics. On the international political stage, the voices of Kurdish activists and diplomats remain marginal, and the floor is being given over to the ruling AKP and its initiative addressing the Kurdish issue, which receives warm support. AKP measures have been confined mostly to soft options that could count upon the approval of most European politicians. The Kurdish issue has become somewhat depoliticized in the eyes of the European outsiders, as well as a majority of the Turkish public.

In contrast to this de-politicization, Kurdish political activists and their supporters have become increasingly political in recent years. The continuous isolation of the Kurdish movement appears to have led to a sharpened Kurdish nationalist discourse, with rising Kurdish demands (as compared to the years immediately following Öcalan's arrest) and an increase in Euro-scepticism amongst Kurdish activists and diplomats. Actions undertaken by PKK-related groups in Europe meanwhile, their efforts to have the Kurds rally around the PKK leadership, evidence a resolute unwillingness to be sidelined.

\footnotetext{
${ }^{13}$ It was through Öçalan, declared Ahmet Türk (ex-DTP leader), that DTP MPs reversed their decision to resign their seats (reported at: http://www.hurriyet.com.tr/gundem/13242730.asp).
} 
'We have to find a way to explain that this is not a good approach to the reality of the Kurds' - in search of political restoration.

Faced with the 'terrorist' label, the PKK and affiliated organizations and parties have developed a number of coping strategies in order to regain their political legitimacy and seek political restoration. Legal and political initiatives have been taken and social-political protest events launched. The many quotations in this paper, stemming from the interviews and observations conducted by the author, also bear testimony in themselves to the efforts of Kurdish political activists to seek political recognition.

The PKK debated the justice of the terrorist designation before the European court in Luxemburg (as mentioned), through its representatives in the Kurdistan National Congress (KNK) and Abdullah Öcalan's brother Osman. Arguments objecting to the listing on substantive grounds became untenable with the end of the unilateral ceasefire in 2004 and bomb blasts in western Turkish cities in 2005 and 2006, according to one of the lawyers on the case (personal communication, London, 27 July 2009), so the case was won only on procedural grounds of due process. However, the verdict did not affect the later listings and the PKK by the EU.

A range of other legal efforts have been undertaken with the intention of restoring the legitimacy of the PKK. A conference was held at prestigious British Chattam House over the question whether or not the PKK could be considered a non-state armed group and, consequently, fall within the confines of International War and Humanitarian Law. The same question was also addressed at the 2007 EUTCC conference, where many of the debates that year pointed in particular to the need to incorporate the PKK into negotiations over the future of Turkey's Kurdish question and its resolution. More generally, a large part of the lobbying work of the European Parliament by Kurdish organizations and other groups and individuals has been directed at the creation of a political space which is inclusive of the PKK, and thus devoted to the survival and strengthening of the position of the party and its leader (Casier 2011). This goal was also actively pursued by the DTP in their diplomatic activities:

\footnotetext{
'We want to exchange views with the EU. We want to make clear to them what the problem is and make clear what we demand. Many institutions that are responsible for the activities in Europe are being closed down. We want them to be able to do their job again. But the main issue is to remember what the problem is and what the solutions can be, for example through conferences. Due to calling the PKK terrorist, all institutions are now being called terrorist. We have to find a way to explain that this is not a
} 
good approach to the reality of the Kurds' (Selahattin Demirtaş, personal communication Diyarbakir, 22 September 2007).

To this end, a comprehensive effort has been undertaken by the International Initiative 'Freedom for Abdullah Öcalan - Peace in Kurdistan'. This association has aimed at the international restoration of Öcalan's position as the political leader of the Kurds, since his capture and imprisonment in 1999. Former lawyers of Öcalan have been involved in its activities, which include the pursuit of various strategies aimed at bringing Öcalan to the foreground in the international community. Öcalan's defence texts (presented at the Court of Athens and at the European Court of Human Rights) were published in book form and his ideological changes and demands presented in several brochures and leaflets in different European languages. The Initiative has also undertaken continuous actions to call for a condemnation of Öcalan's prison conditions on Imralli island, rallied for support for Öcalan in the Council of Europe and obtained a number of members to sign a motion for resolution on 'The state of health of Mr. Abdullah Öcalan.'

In 2006 the Freedom Initiative co-organized another major campaign launched by KONKURD, the umbrella federation of all Kurdish federations in Europe. The campaign called upon the Kurds to sign a petition in which they would declare: 'I, from Kurdistan, recognize Mr. Abdullah OCALAN as a political representative in Kurdistan. ${ }^{14}$ Some three and a quarter million people 'from Kurdistan' have signed the petition to date. The petition was handed over to the European Parliament and the Council of Europe to send a clear message that Öcalan - given his popular support - should be incorporated in the negotiations over a resolution of the Kurdish issue. In 2009, the International Initiative was actively involved in sustaining Öcalan's initiative to push forward a roadmap to peace.

In Britain, meanwhile, an international initiative of political organizations from different countries that found themselves on the UK terrorist list was established, in which the PKK is involved. CAMPACC has been operating in coordination with the Peace in Kurdistan campaign and the Kurdish National Congress (KNK) London and also started a petition addressed to the British government calling for the delisting of the PKK in Great Britain and aiming at the collection of 10000 signatures.

\footnotetext{
${ }^{14}$ URL: http://www.freedom-for-ocalan.com/english/aktuell/campaign/konkurd-form.pdf.
} 
This brief sketch of initiatives gives an impression of some of the approaches being taken in support of the PKK in Europe. The International Initiative was successful in pressuring the CPT to conduct fact-finding missions and bring members of the Council of Europe to adopt a resolution on Abdullah Öcalan, ultimately leading to a reconsideration in Turkey of his prison conditions. Other initiatives, such as the petition that gathered over three million signatures did not seem to have a very clear direct impact. Taken as a whole, however, these initiatives do testify to the ongoing popularity of the PKK and its leader, indicative of the problematic nature of its designation as mere terrorists.

\section{THE PKK IMPACT ON AND THE TURKEY-EU ACCESSION PROCESS}

The PKK seeks both national and international recognition as the main representative of Turkey's Kurds. This quest is undoubtedly problematic in that it foregoes political and societal realities inside the country, where Kurds greatly differ in the extent to which they identify with their ethnicity, and how they relate their personal daily concerns to the political aspirations and promises of different political parties. Given that it swept the elections in the South-East during its early years in office, one could argue - and it has indeed been argued by Prime Minister Erdoğan himself - that the ruling AKP is the primary representative of the Kurds (Bahcheli \& Sid, 2011). However, even a majority in numbers is merely that: it does not undo the significant impact that the PKK as a social-political movement has in the region. This impact translates into votes for the DTP/BDP, and the Kurdish constituents certainly do consider a vote for the pro-Kurdish parties to be 'voting PKK' (Marcus 2007b).

Over the last two decades an alternative socio-political reality has come into being in the Kurdish dominated region of Turkey. It is unlikely that any 'Kurdish initiative' that neglects this reality or, for that matter, seeks to 'win back to society' the populace there will succeed in the short run. It is to be expected that huge numbers of politicized Kurdish citizens will continue to appoint the DTP/BDP and thus indirectly the PKK to speak on their behalf. A continued neglect of this reality, and/or active policies to hamper these political (and societal) actors through judicial short-winging and counter-terrorism, promises ongoing disengagement of this part of the Kurdish constituency from the Turkish state and society and increases Kurdish nationalist demands (see also Casier, Jongerden \& Walker, forthcoming). The apparent deepening of mass support for the DTP/BDP against the AKP and the hardening of the Kurdist position appear as evidence for this. 
Obviously the ongoing refusal to enter into negotiations with the 'terrorists' (and ultimately a process of political integration) provides little incentives for the PKK to entirely abandon armed struggle as a resource. Therefore the armed campaign continues, even though it has become a low-intensity conflict in the post 1999 era. Indeed, Kurdish activist perceptions of the Kurdish opening as culminating in the closure of the DTP have already led, it would seem, to the suspension of the PKK ceasefire in the summer of 2010 and a 'a new era' of violence. What form this new era may take is unclear, but there certainly seems to be a 'higher risk' in particular of PKK attacks on 'high profile, relatively soft, targets in the cities of western Turkey' (Jenkins 2010) - or, terrorism, by any standards.

The continued violence brings along new grievances on both sides, constantly reviving both Turkish and Kurdish nationalist feelings that then translate into further societal friction, including civil unrest and the outward discrimination of Kurdish citizens in Turkish cities (Yeğen, 2011; Kentel, 2011). A destabilizing factor in Turkish politics, the continuation of the armed conflict thus raises serious internal (as well as cross-border) security issues. This is all the more so as the continuation of the conflict, and the anti-terror policies that accompany it, allow for undue restrictions in the spheres of the freedom of speech, freedom of press, freedom of organization and the freedom of political parties, and thus slows down the needed legal and judicial reforms in Turkey.

It is exactly these consequences that affect the Turkey-EU accession process, wherein Turkey's human rights records and the process of democratization, demanding both political demilitarization and a depoliticization of the Turkish judiciary, have been continuous matters of concern for the member-states, the European Commission, the Council of Europe and the European Parliament (see Tocci, 2005). Indeed, the continued raising of these concerns is also what led (in the first half of the 2000s) to a number of accommodations of the Kurdish demands in Turkey that could never have been realized were it not for the bargaining space the EU provided the successive the Turkish governments. However, the ongoing atmosphere of 'being under threat' places serious obstacles in front of any government that wants to go ahead with the necessary reforms in the crucial domains of the judiciary and the military. A politically negotiated solution of the Kurdish issue, including the armed conflict is therefore intimately linked with the success or failure of the Turkey-EU accession process.

\section{CONCLUSION}


The designation of the PKK as an international terrorist organization has seriously affected the Kurdish nationalist movement and its supporters' trust in the international institutions, particularly the EU. This has brought some scholars, notably Uslu (2008), to the reasonable conclusion that the PKK has turned against Turkey's accession to the European Union. Nevertheless, the evidence presented in this paper suggests a different interpretation of the PKK position, that the criticisms and the diminishing support for accession amongst the Kurdish constituents be understood first, in the context of the position in Turkey - with the competition from the AKP - and second, in the context of the PKK proscription as a terrorist organization and the associated pressure brought to bear on the politically successful DTP. With this in mind the strong anti-EU rhetoric of the PKK can be seen as one part of its ongoing struggle to (re)gain political legitimacy and create a political space that is inclusive of the movement that represents Turkey's most politicized Kurds.

The coming months and years will therefore be decisive for the PKK as it chooses whether or not to continue to support or opt out of the Turkey-EU accession negotiations. The thrust of this paper is to suggest that this is certainly not yet decided; the PKK has not renounced its support of Turkey's accession to the European Union, but rather has come to make its support conditional upon its own recognition as a political actor in the negotiations in particular, and Turkey's politics more generally. If the EU continues to list the PKK as a terrorist group and pressure the pro-Kurdish party in Turkey (now BDP) on its PKK relationship, then those (historically dominant) forces in Turkey that prefer to neglect Kurdish political representation will be further strengthened. Politically ignored and no longer militarily able to fight a guerrilla war, the PKK may indeed feel pushed towards full blown terrorism. The terrorist listing may become a self fulfilling category for another generation to deal with. 


\section{REFERENCES}

Adamson, F. (2002) Mobilizing for the Transformation of Home: Politicized Identities and Transnational Practices, in: Al-Ali, N. and K. Koser (Eds.) New Approaches to Migration? Transnational Communities and the Transformation of Home (London: Routledge).

Akkaya, A.H. and J. Jongerden (2011) The PKK in the 2000s: Continuity through breaks?, in: M. Casier \& J. Jongerden, J. (Eds) Nationalisms and politics in Turkey: political Islam, kemalism and the Kurdish issue (London: Routledge).

Bahcheli, T. and S. Noel (2011) The Justice and Development Party and the Kurdish Question, in: M. Casier \& J. Jongerden (Eds) Nationalisms and politics in Turkey: political islam, kemalism and the Kurdish issue (London: Routledge).

Casier, M. (2010) Turkey's Kurds and the Quest for Recognition. Transnational Politics and the EU-Turkey accession negotiations, Ethnicities, 10 (1), pp.3-25.

Casier, M. (2011) The Politics of Solidarity. The Kurdish Question in the European Parliament, in: M. Casier \& J. Jongerden, J. (Eds) Nationalisms and politics in Turkey: political Islam, kemalism and the Kurdish issue (London: Routledge).

Casier, M., A. Hilton \& J. Jongerden (2009) "Road Maps" and Roadblocks in Turkey's Southeast, Middle East Report Online, 30 October 2009.

URL: http://www.merip.org/mero/mero103009.html

Cizre, Ü. (2008) Ideology, context and interest: the Turkish Military, in: Kasaba, R. (Ed.) The Cambridge History of Turkey. Volume 4. Turkey in the Modern World (Cambridge: Cambridge University Press).

Eccarius-Kelly, V. (2002) Political Movements and Leverage Points: Kurdish Activism in the European Diaspora, Journal of Muslim Minority Affairs, 22 (1), pp.91-118.

EC (2001) Council Common Position 2001/931/CFSP of 27 December 2001 on the application of specific measures to combat terrorism.

URL: http://eur-lex.europa.eu/LexUriServ/LexUriServ.do?uri=OJ:L:2001:344:0093:0096:EN:PDF 
EC (2002) Council Common Position 2002/340/CFSP of 2 May 2002 updating Council Common Position 2001/931/CFSP on the application of specific measures to combat terrorism.

URL: http://eur-lex.europa.eu/LexUriServ/LexUriServ.do?uri=OJ:L:2002:116:0075:0077:EN:PDF

EC (2004) Council Common Position 2004/500/CFSP of 17 May 2004 updating Common Position 2001/931/CFSP on the application of specific measures to combat terrorism and repealing Common Position 2004/309/CFSP.

URL: http://eur-lex.europa.eu/LexUriServ/LexUriServ.do?uri=CELEX:32004E0500:EN:HTML

EC (2009) Turkey 2009 Progress Report, October 14th 2009 (Doc. SEC(2009)1334), Brussels: Commission Staff Working Document.

URL: http://ec.europa.eu/enlargement/pdf/key_documents/2009/tr_rapport_2009_en.pdf

EP (2008) Report on Turkey's 2007 progress report (2007/2269(INI)), European Parliament: Committee on Foreign Affairs (A6-0168/2008).

URL: $\quad$ http://www.europarl.europa.eu/sides/getDoc.do?pubRef=-//EP//NONSGML+REPORT+A6$\underline{2008-0168+0+\mathrm{DOC}+\mathrm{PDF}+\mathrm{V} 0 / / \mathrm{EN}}$

Gambetti, Z. (2008) Conflict, 'commun-ication' and the role of collective action in the formation of public spheres, in: Shami, S., (ed.) Publics, Politics and Participation: Locating the Public Sphere in the Middle East and North Africa (New York: SSRC Books).

Gambetti, Z. (2008) Decolonizing Diyarbakir: culture, identity and the struggle to appropriate urban space, in: K. A. Ali and M. Rieker (Eds) Re-exploring The Urban: Comparative Citiscapes in the Middle East and South Asia (Karachi: Oxford University Press).

Grojean, O. (2008) La cause kurde, de la Turquie vers l'Europe, Phd. Thesis, Ecole des Hautes Etudes en Sciences Sociales, Paris. URL: http://oliviergrojean.hautetfort.com/these/

Gunter, M. (2008) The Kurds Ascending. The Evolving Solution to the Kurdish Problem in Iraq and Turkey (New York: Palgrave/McMillan).

Jenkins G. (2009) After DTP closure: from dialogue to monologue?, Turkey Analyst, vol. 2 no. 23. URL: http://www.silkroadstudies.org/new/inside/turkey/2009/091221A.html.

Jenkins G. (2010) The PKK insurgency enters a new era, Turkey Analyst, vol. 3 no. 12. URL: http://www.silkroadstudies.org/new/inside/turkey/2010/100621A.html. 
Jongerden, J. (2007) The Settlement Issue in Turkey and the Kurds. An Analysis of Spatial Policies, Modernity and War (Leiden: Brill Publishers).

Jongerden, J. \& A. Akkaya (2011) Born from the Left. The making of the PKK, in: Casier, M. \& J. Jongerden (Eds.) Nationalisms and Politics Turkey: political islam, kemalism and the Kurdish issue (London: Routledge).

Kentel,F (2011) 'Nationalist' reconstructions in the light of disappearing borders, in: Casier, M. \& J. Jongerden (Eds.) Nationalisms and Politics Turkey: political islam, kemalism and the Kurdish issue (London: Routledge).

Østergaard-Nielsen, E. K. (2001) The Politics of Migrants' Transnational Political Practices, Paper presented at the Conference on Transnational Migration: Comparative perspectives, Princeton University, June-July.

Öktem, K. (2008) The patronising embrace: Turkey's new Kurdish strategy, Occasional Paper, Stiftung Forschungsstelle Schweiz-Türkei and Kerem Öktem, Basel, February 2008. URL: http://www.sfst.ch/typo3/fileadmin/user_upload/dateien/OP_Oktem_08-02.pdf

Marcus, A. (2007a) Turkey's PKK: Rise, Fall, Rise Again? World Policy Journal, Spring, pp.74-84.

Marcus, A. (2007b) Blood and Belief. The PKK and the Kurdish Fight for Independence (New York/London: New York University Press).

Mc Dowall, D. (1996) A modern history of the Kurds (London/New York: IB Tauris).

Romano, D. (2006) The Kurdish Nationalist Movement: Opportunity, Mobilization and Identity (Cambridge: Cambridge University Press).

Posch, W. (2007) Crisis in Turkey: just another bump in the road to Europe? EUISS Ocassional Papers 67 (Paris: European Union Institute for Security Studies).

URL: http://www.iss.europa.eu/uploads/media/occ67.pdf

Sheper-Hughes, N. \& Bourgois, P. (2008) (Eds) Violence in War and Peace. An Anthology (Malden/Oxford: Blackwell Publishing).

Taspinar, O. (2005) Kurdish Nationalism and Political Islam in Turkey. Kemalist Identity in Transition (London: Routledge). 
Tocci, Nathalie (2005) 'Conflict Resolution in the Neighbourhood: Comparing the Role of the EU in the Turkish-Kurdish and Israeli-Palestinian Conflicts', CEPS Working Documents No. 221.

UK (2001) The Terrorism Act 2000 (Proscribed Organisations) (Amendment) Order 2001 (Statutory Instrument 2001 No. 1261) (London: Queen's Printer of Acts of Parliament). URL: $\underline{\text { http://www.opsi.gov.uk/si/si2001/20011261.htm }}$

Uslu, E. (2008) The Kurdistan Workers' Party Turns against the European Union. Mediterranean Quarterly, 19(2), pp.99-120.

Van Bruinessen, M. (1998) Shifting national and ethnic identities, Journal of Muslim Minority Affairs, 8 (1), pp.39-53.

Watts, N.F. (2006) Activists in Office: Pro-Kurdish Contentious Politics in Turkey, Ethnopolitics, 5(2), pp.125-144.

Watts, N.F. (2004) Institutionalizing Virtual Kurdistan West: Transnational Networks and Ethnic Contention in International Affairs, in: J. S. Migdal, Boundaries and Belonging: States and Societies in the Struggle to Shape Identities and Local Pratices (Cambridge: Cambridge University Press).

Yeğen, M. (2011) The Kurdish question in Turkey: denial to recognition, in: Casier, M. \& J. Jongerden (Eds.) Nationalisms and Politics Turkey: political islam, kemalism and the Kurdish issue (London: Routledge). 